\title{
Benefit Sharing
}

\section{Combining Intellectual Property, Trade Secrets, Science and an Ecosystem- Focused Approach}

\author{
Marcel Jaspars and Abbe E. L. Brown
}

\begin{abstract}
This contribution develops a new approach to benefit sharing in areas beyond national jurisdiction. It has regard to a breadth of relevant legal regimes, sustainability, the needs of science, analogies with Farmers Rights and the prospect of increased involvement of the commercial sector. Proposals are made for the benefit sharing regime to cover digital sequences of marine genetic resources; for restrictions to be imposed on the rights of IP owners and controllers of trade secrets to enable delivery of a balanced approach to benefit sharing; for an open sharing of the results of research cruises; for a pragmatic and deliverable approach to tracing use of marine genetic resources across present and future development pipelines; and for different approaches to be taken to benefit sharing in respect of ecologically sustainable technologies and to encourage their pursuit. The proposals are marked in italics.
\end{abstract}

\section{Keywords}

benefit sharing - intellectual property - bioprospecting - ecosystem-focused approach - sustainability - marine genetic resources - areas beyond national jurisdiction - traceability - trade secrets - science - Mare Geneticum

This interdisciplinary contribution made from law and science develops proposals to deliver a pragmatic means to share the benefit arising from marine genetic resources (MGR). Benefit sharing of MGR is one of the issues covered by a commitment under the United Nations Convention on the Law of the Sea 
(UNCLOS) $)^{1}$ to create an internationally binding legal instrument (ILBI) on the conservation and sustainable use of marine biological diversity of areas beyond national jurisdiction (ABNJ). ${ }^{2}$ This proceeds in the context of MGR's importance being highlighted at the Intergovernmental Panel on Climate Change meeting in Monaco in 2019, given its potential contribution to industry transition and nature-based solutions. ${ }^{3}$ This and other uses of MGR require work with unexplored and extreme environments such as the cryosphere, deep oceans and thermal vents ${ }^{4}$ - and all of these can be found within ANBJ. ${ }^{5}$

Benefit sharing will be developed here by taking an ecological and ecosystem approach, reflecting the climate change intersection just noted; by including genetic sequence information about MGR, as well as physical MGR samples, which reflects evolving scientific realities; by engaging with intellectual property (IP) rights and trade secrets reflecting the contribution these rights can make to delivery (and non delivery) of benefit sharing; by engaging more deeply with tracing and digital identifers; and by evaluating how widely benefit sharing could and should extend along the research and commercialisation pipeline, which reflects the need to reward, incentivise and increase knowledge development, information sharing and coordination as well as investment. A new means of benefit sharing will be put forward which combines respect for sustainability, different relevant laws and scientific reality and workability.

1 United Nations Convention on the Law of the Sea 1833 UnTS p. 3. For a general discussion of marine environmental protection under UNCLOS see J. Harrison, Saving the Oceans through Law: The International Legal Framework for the Protection of the Marine Environment, (Oxford, Oxford Univeristy Press, 2017) 17-63.

2 Ibid. 296-9; R. Warner, 'Oceans of Opportunity and Challenge: Towards a Stronger Governance Framework for Conservation and Sustainable Use of Biodiversity in Marine Areas Beyond National Jurisdiction' 3 Asia-Pacific Journal of Ocean Law and Policy (2018) 157 (Warner). See also United Nations webpage Intergovernmental Conference on Marine Biodiversity of Areas Beyond National Jurisdiction https://www.un.org/bbnj/ accessed 2 November 2019 (UN site). Reference is made below (see n. 24-7) to specific resolutions made in this process.

3 IPCC, 'Special Report on the Ocean and Cyrosphere in a Changing Climate' (2019) https:// www.ipcc.ch/srocc/home/ accessed 2 November 2019.

4 See e.g., Industrial Biotechnology Innovation and Growth Team, 'Maximising UK Opportunities from Industrial Biotechnology in a Low Carbon Economy: A report to the government by the Industrial Biotechnology Innovation and Growth Team' (Ів 2025, May 2009) http:// beaconwales.org/uploads/resources/Maximising_UK_Opportunities_from_Industrial_Biotechnology_in_a_Low_Carbon_Economy.pdf accessed 2 November 2019.

5 J. Cone, Fire under the Sea. The Discovery of the Most Extraordinary Environment on Earthvolcanic hot springs on the ocean floor (New York, William Morrow and Co., 1991); Royal Society, 'Future ocean resources: metal-rich minerals and genetics - evidence back' (2017) https://royalsociety.org/ /media/policy/projects/future-oceans-resources/future-of-oceansevidence-pack.pdf accessed 2 November 2019 (Royal Society) 39-41. 


\subsection{The Scientific Pathway}

UNCLOS, adopted in 1982, did not address MGR, even though deep sea biodiversity has been known since the Challenger expeditions explored the north and south Atlantic and the Pacific in $1872-6.6$ It has been suggested that UNCLOs's position arose from the fact that the value of deep-sea marine biodiversity was not generally appreciated until the 1990s, with technology not being available to exploit the resources; ${ }^{7}$ and conversely that MGR was deliberately not addressed because of uncertainty as to how to balance the interests of the commercial sector with enabling all (in particular scientists) to benefit in different ways from the use of these resources. ${ }^{8}$

Access to deep sea biodiversity is indeed challenging because of the level of engineering and financial input (including research vessels, deep sea sampling systems and remotely operated vehicles) which is needed to collect MGR. ${ }^{9}$ Yet awareness of the commercial and societal gain which could arise as a result grew over time. ${ }^{10}$ From 1969 onwards, there was work on reef organisms such as sponges, seasquirts and soft corals and from the early 1990s scientists investigated marine bacteria from marine sediments (which are easier and less expensive to collect) for microbially-derived compounds to provide novel bioactive molecules. ${ }^{11}$ In the early 21 st century, there were some successes in use of MGR-derived clinical applications of anti-cancer medicines, but industrial natural product drug discovery was then de-emphasised as industry pursued,

6 The Challenger Society for Marine Science, 'The History of the Challenger Expedition' https://www.challenger-society.org.uk/History_of_the_Challenger_Expedition accessed 2 November 2019 .

7 D. Freestone, 'The UN Process to Develop an International Legally Binding Instrument under the 1982 Law of the Sea Convention: Issues and Challenges' $3-5$ in D. Freestone (ed.) Conserving Biodiversity in Areas Beyond National Jurisdiction (Leidon, Brill Nijhoff, 2019) (Freestone). A landmark piece is L. Glowka, 'The Deepest of Ironies: Genetic Resouces, Marine Scientific Research, and the Area' 12(1) Ocean Yearbook Online (1996) 154. See also R. Tiller et al., 'The once and future treaty: Towards a new regime for biodiversity in areas beyond national jurisdiction' 99 Marine Policy (2019) 239-242, 1.4; C. Correa, 'Access to and Benefit Sharing of Marine Genetic Resources Beyond National Jurisdiction: Developing a new Legally Binding Instrument' South Centre Research Paper 79 Sept. 2017 (Correa).

9 A. Jamieson, The Hadal Zone: Life in the Deepest Oceans (Cambridge, Cambridge University Press, 2015), Part I.

10 K. ten Kate and S. A. Laird, The Commercial use of biodiversity: access to genetic resources and benefit-sharing (London, Earthscan, 1999) (Kate/Laird) 3·3·3, 9.

11 See Midwestern University, 'Clinical Pipeline: Marine Pharmacology: Approved Marine Drugs' https://www.midwestern.edu/departments/marinepharmacology/clinical-pipeline. xml accessed 2 November 2019. 
fairly unsuccessfully, more technological paths such as combinatorial chemistry and high-throughput screening methods. ${ }^{12}$ This, and growing understanding of the molecular mechanisms by which bioactive natural products are made, means that natural product drug discovery is experiencing a resurgence at the time of writing in 2019. ${ }^{13}$ It has been observed that "sustainable use of these novel resources could have significant benefits ... The high biodiversity in the ocean, including species adapted to a range of extreme environments provides a substantial resource for development of new chemicals, including antibiotics and cancer treatments". ${ }^{14}$ Opportunities also lie in delivering bioenergy and ecological solutions, cosmetics, household products and nutraceuticals. ${ }^{15}$

\subsection{Legal Pathways}

Uncertainty continues about the extent to which these opportunities will come about - consider that in 2017, 30,00o relevant molecules had been identified and nine related products had been brought to market - however, the pipeline appears to be becoming more productive. ${ }^{16}$ Given this prospect of greater commercial interest in MGR, it is timely that the United Nations is addressing conservation and sustainable use of MGR, including the sharing of benefits derived from MGR. Industry has met nature before - on land and in ocean areas which are within national jurisdiction, leading to the Convention on Biological Diversity $1992^{17}$ and then the Nagoya Protocol on fair and equitable sharing of

12 See T. Kodadek, 'The rise, fall and reinvention of combinatorial chemistry' 55 Chemical Communications (2011) 47, 9757-9763.

13 S. Pearce, 'A Resurgence in Natural Product-Based Drug Discovery: Advances in analytical technology are making the screening of natural products and their substructures more viable' 13(2) PharmTech (2018) http://www.pharmtech.com/resurgence-natural-productbased-drug-discovery accessed 2 November 2019 .

14 Royal Society, above n. 5 at 5, and more detailed analysis of MGR $3^{2-6}$, with discussions of uses from 43 .

15 R Blasiak et al., "The Ocean Genome: Conservation and the Fair, Equitable and Sustainable Use of Marine Genetic Resources' (High Level Panel for a Sustainable Ocean Economy) https://oceanpanel.org/ocean-genome-conservation-and-fair-equitable-andsustainable-use-marine-genetic-resources accessed 2 November 2019 (Blasiak).

16 Royal Society, 42-3; see also Correa n 8, 4, 6 referring to Pharmasea project on which Jaspars was involved, see http://www.pharma-sea.eu/ accessed 2 November 2019; D. Skropeta, 'Deep-sea natural products' 25 Natural Products Reports (2008) 1131-1166 reviewing 390 marine natural products from deep water to 2007; E. Heafey 'Access and Benefit Sharing of Marine Genetic Resources from Areas beyond National Jurisdiction: Intellectual Property--Friend, Not Foe' 14(2) Chicago Journal of International Law 2014, Article 5 (Heafey), 495-6; Correa, 15-6 referring to 2015 report of National Institute of Genetics https://www.nig.ac.jp/nig/pdf/about_nig/youran2014.pdf accessed 2 November 2019.

17 Convention on Biological Diversity 1992 176o UnTs p. 39, arts. 1, 15 (in particular (3) and (7)), 16, 19, 20, 21. 
benefits. ${ }^{18}$ Nagoya does not address the needs of MGR in ABNJ as it takes in the main a bilateral approach and under UNCLOS no one can own or transfer resources from the ABNJ. ${ }^{19}$ Yet a common theme in these UNCLOS discussions is the risk of taking an approach to benefit sharing in $\mathrm{ABNJ}$ which is too radically different to Nagoya; this is because it could create extra burdens on capacity, given that some forms of MGR (say the larvae from sponges) may be found within and outside national jurdsictions or move from one to the other. ${ }^{20}$

For MGR in ABNJ, the international policy start came in 2004 when the UN General Assembly ${ }^{21}$ established an Ad Hoc Open-Ended informal Working Group (Working Group) to study issues relating to the conservation and sustainable use of marine biological diversity beyond areas of national jurisdiction. ${ }^{22}$ The Rio+2o meeting in 2012 of the United Nations Conference on Sustainable Development referred to the Working Group and called for the ABNJ to be addressed at UNCLOS. ${ }^{23}$ In 2015 a United Nations General Assembly resolution ${ }^{24}$ established a Preparatory Committee to make recommendations on elements of a text, taking into account reports of the Working Group. ${ }^{25}$ In 2018, the UN General Assembly ${ }^{26}$ convened an Intergovernmental Conference (IG C) to consider the recommendations of the Preparatory Committee and to develop the text of an IBLI to address ensuring sustainable use of biodiversity, in particular "together and as a whole", ${ }^{27}$ MGR and access and benefit sharing (the

18 See text https://www.cbd.int/abs/text/ accessed 2 November 2019. See in particular art. 10 and analysis in E. Morgera, E. Tsiomani and M. Buck, (eds.) Unraveling the Nagoya Protocol - A Commentary on the Nagoya Protocol on Access and Benefit-sharing to the Convention on Biological Diversity (Leiden, Brill, 2014) (Morgera et al.).

19 Nagoya Protocol, art. 6(1) prior informed consent although note art 10 regarding discussion about a global multilateral benefit-sharing mechanism, 6(3), 7, 8 regarding mutually agreed terms; UNCLOS art. 137(2) - there are possibilities in respect of minerals.

20 M. R. Muller, Genetic Resources as Natural Information: Implications for the Convention on Biological Diversity and Nagoya Protocol (Abingdon, Earthscan/Routledge, 2015) (Muller), 39-41, 67 .

21 GA59/24 para 73.

22 See https://www.un.org/Depts/los/biodiversityworkinggroup/biodiversityworkinggroup. htm accessed 2 November 2019 .

23 Rio+2o Future We Want Outcome Document https://sustainabledevelopment.un.org/ index.php?menu=1298accessed 2 November 2019, para 16.

24 A/Res/69/292 (6 July 2015): Development of an international legally binding institution under the United Nations Convention on the Law of the Sea on the conservation and sustainable use of marine biological diversity of areas beyond national jurisdiction.

25 See webpage of Preparatory Committee https://www.un.org/depts/los/biodiversity/prepcom.htm accessed 2 November 2019 .

26 A/Res/72/249.

27 Ibid., art. 2. 
focus here), area based management tools including marine protected areas, environmental impact assessments, technology transfer and capacity building. ${ }^{28}$ The first draft ILBI text was published in June $2019^{29}$ after negotiations at two IG Cs. ${ }^{30}$ At the time of writing in late 2019, this draft has been discussed by states, IGO s and NGO s at $\mathrm{IGC}_{3},{ }^{31}$ and a further draft is awaited. There will be a fourth IGC in March-April 2020 and a meeting at the General Assembly to adopt the ILBI later in that year.

\section{$3 \quad$ Mare Geneticum and Beyond}

This proposal uses as a base a proposal Mare Geneticum, developed in the context of the ILBI by scientists (including one of the authors), lawyers and policy makers. It provides a fair means of encouraging and rewarding research and development into MGR from ABNJ, and of sharing the benefits resulting from this work. ${ }^{32}$ Points of particular interest here relate to the sharing of the results of all research cruises through the deposition of data in a series of linked public databases to enable further scientific activity, capacity building and later commercial product development, and to the initial researchers having an exclusivity period - and also the option of a paid extension to it (with amounts

28 See analysis in E. Morgera, 'Competence or Confidence? The Appropriate forum to Address Multi-Purpose High Seas Protected Areas' 16 Review of European, Comparative and Internanational Environmental Law (2007) 1 and Warner, above n. 2, 162-4.

29 Intergovernmental Conference on Marine Biodiversity of Areas Beyond National Jurisdiction, 'Draft text of an agreement under the United Nations Convention on the Law of the Sea on the conservation and sustainable use of marine biological diversity of areas beyond national jurisdiction', 17 May 2019 A/CONF.232/2019/6 (June 2019 draft ILBI).

30 President's aid to discussions for IGC 1 A/CONF.232/2018/3 and Aid to Negotiations for IGC 2 A/CONF. 232/2019/1*; E. Mendenhall, E. De Santo, E. Nyman, R. Tiller, 'A soft treaty, hard to reach: The second inter-governmental conference for biodiversity beyond national jurisdiction' 108 Marine Policy (2019) 103664 for a valuable review of the negotiation process at IGC $2-4.1 .1$ on MGR noting the "plodd[ing] by delegates" through a detailed "Aid to Negotiations" which contained various options; and D. Leary, "Agreeing to disagree on what we have or have not agreed on: The current state of play of the B BNJ negotiations on the status of marine genetic resources in areas beyond national jurisdiction' 99 Marine Policy (2019) 21-29 (Leary).

31 See resources via "Third substantive session" https://www.un.org/bbnj/content/thirdsubstantive-session and reports via Earth Negotiations Bulletin https:/enb.iisd.org/ oceans/bbnj/igc3/ both accessed 2 November 2019.

32 T. Vanagt, A. Broggiato, L.E. Lallier, M Jaspars, G. Burton and D Muyldermans, 'Mare Geneticum: Towards an Implementing Agreement for Marine Genetic Resources in International Waters' 27 in Freestone, above n. 7 . 
to be established with reference to the sector) with proceeds from this going to a biodiversity fund. Compliance with these information and payment provisions could be through a system of digital identifiers. In addition, Mare Geneticum proposed that the biodiversity fund would support capacity building for scientists from developing areas and that there would be prior electronic notification of research activity (alongside separate requirements for environmental impact assessments) in advance of the research cruise, with the details to be updated afterwards. ${ }^{33}$ Elements of Mare Geneticum are included in the ILBI draft text. ${ }^{34}$

Mare Geneticum was put forward in the context of provisions in UNCLOS regarding the rights to states to engage in marine scientific research, ${ }^{35}$ and that carrying out that marine scientific research is to be subject to the freedom of the high seas, ${ }^{36}$ which could mean that anyone could have access to the MGR on a first come first served basis and profit from it without the need to share any benefit arising. ${ }^{37}$ Yet UNCLOS also provides that ABNJ, (and importantly their resources) are the common heritage of mankind. ${ }^{38}$ These two different approaches have given rise to significant debate regarding the legal basis for benefit sharing with respect to MGR. ${ }^{39}$ Mare Geneticum provides a pragmatic solution. Further, Mare Geneticum is consistent with some other proposals for a holistic approach to benefit sharing in relation to MGR

33 See June 19 draft ILBI, above n. 29, arts. 22-39.

34 See June 19 draft ILBI, above n. 29, arts. 10.1, 11.3 (a), 52.5.

35 UNCLOS, art. 238 see also art 240 (d) referring to the rest of UNCLOS.

36 Although this is not an unfettered provision, see UNCLOs, art 87(1)(f) and art 87(2) referring notably to rights in respect of activities in $\mathrm{ABNJ}$.

37 Leary, above n. 30, 3.1; Glowka, above n. 8, 155 suggesting that MGR falls under freedom of the high seas.

38 UNCLOS, arts. 133, 136, 137(2), 140 .

39 C. Salpin, 'The Law of the Sea: A before and after Nagoya' (Salpin) in Morgera et al., above n. 18, 153-6; D. Tladi, 'Conservation and sustainable use of marine biodiversity in areas beyond national jurisdiction: towards an implementing agreement' in R. Rayfuse (ed.) Research Handbook on International Marine Environmental Law (Cheltenham, Edward Elgar, 2015) 259, 26o-3; Heafey, above n.16, 508-9; K. Marciniak, 'Marine Genetic Resources: do they Form Part of the Common Heritage of Mankind Principle?' in L. Martin, C. Salondia, C. Hioureas (eds.), Natural Resources and the Law of the Sea: Exploration, Allocation, Exploitation of Natural Resources in areas under National Jurisdiction and Beyond (JuristNet, 2017) engaging in particular with treaty interpretation under the Vienna Convention on the law of Treaties and levels of awareness of scientific opportunities, and concluding that MGR in the ABNJ is subject to freedom of the high seas but that there is a place for Part XI of UNCLOS regarding common heritage in regulation of these MGR. 
with a focus on technology transfer and capacity building and data sharing ${ }^{40}$ and for the generation of a common fund. ${ }^{41}$ There are also new arguments for benefit sharing to be a theorised, independent concept grounded in equity ${ }^{42}$ and one which delivers "deeper and cosmopolitan international cooperation". 43

These proposals for benefit sharing, particularly from the theoretical perspective, could empower the taking of new positions to MGR in the ILBI. These new positions could draw on other benefit sharing regimes (beyond Nagoya) ${ }^{44}$ and also address issues which are arising from evolving attitudes and technology. ${ }^{45}$ An example of such a point is the challenge to Mare Geneticum's period of exclusivity on the basis that it entrenches the first mover advantage of the initial researcher, and in the view that there should rather be a sharing with all, from the start, of the information and samples gained from research cruises. ${ }^{46}$ This would undoubtedly increase the transfer of knowledge and opportunites for collaboration between scientists.

40 H. Harden-Davies and K. Gjerde, 'Building Scientific and Technological Capacity: A Role for Benefit-sharing in the Conservation and Sustainable Use of Marine Biodiversity beyond National Jurisdiction' 33(1) Ocean Yearbook Online (2019) 377 (Harden-Davies and Gjerde), 394-5.

41 Heafey, above n. 16, 518-21, building on the initiatives of the Global Commons Trust.

42 E. Morgera, "The Need for an International Legal Concept of Fair and Equitable Benefit Sharing' 27 The European Journal of International Law (2016), 353 (Morgera, Need), 354, 357, 359, 368, 373, 380-3; E. Morgera, 'Fair and equitable benefit-sharing in a new treaty on marine biodiversity: A principled approach towards partnership building?' (BENELEX Working Paper No.16, 2018) (Morgera, Fair and Equitable), pp. 6-11, 48, 54-7.

43 Morgera, Fair and Equitable, above n. 42, 51.

44 Notably the International Treaty on Plant Genetic Resources for Food and Agriculture 2400 UnTS p. 303 (Plant Treaty) and steps taken at the World Health Organization in relation to the sharing of viruses and pandemic supplies, and/or the First Global Plan of Action for Forest Resources 2014 http://www.fao.org/policy-support/resources/ resources-details/en/c/469497/ accessed 2 November 2019. See Morgera, Fair and Equitable, above n. 42, 54; C. Chiarolla, 'Intellectual property rights and benefit sharing from marine genetic resources in areas beyond national jurisdiction: current discussions and regulatory options' 4(3) Queen Mary Journal of Intellectual Property (2014) 171-194 (Chiarolla), 19o; Correa, above n. 8; Harden-Davies and Gjerde, above n. 40; A. Bonfanti and S. Trevisanut, 'TRIPS on the High Seas: Intellectual Property Rights on Marine Genetic Resources' 37 Brooklyn Journal of International Law (2011) (Bonfanti and Trevisanut) $215^{-220}$ and $223^{-6}$.

45 Muller, above n. 20 66, 70; Bonfanti and Trevisanut, above n. 44, 232.

46 S. Thambisetty, "Marine Genetic Resources beyond National Jurisdiction: Elements of a New Internationally Legally Binding Instrument" LSE Law Policy Briefing 322018 (Thambisetty), in particular value 6 "property begets property". 
An open approach to sharing with scientists can draw from the Plant Treaty, ${ }^{47}$ which created an opportunity (but not an obligation) ${ }^{48}$ for states to create Farmers' Rights. There is also an African Model Law for the protection of farmers and regulation of access to biological resources. ${ }^{49}$ These instruments reflect a recognition of an equitable and sustainable base for special treatment to be accorded to farmers, in the light of the fact that they have stewarded the land over generations as primary custodians..$^{50}$ Farmers' Rights have been referred to as a possible analogy in the context of rewarding past conduct, in proposals for a new specific IP right to protect the needs of investors and bioprospectors. ${ }^{51} \mathrm{~A}$ different perspective to using Farmers' Rights is pursued here. Scientists can fulfil a similar role to farmers - looking after nature and bringing about benefits for all - through their objective analysis of the MGR, and the sharing of this information (which will be considered further below). Accordingly, scientists should be accorded rights in the ILBI, and these should move beyond the peripheral, optional rights in the Plant Treaty. There should be a mandatory benefit sharing ${ }^{52}$ mechanism regarding the sharing of information, payments for and provision of opportunities to participate in cruises. This should enable the virtuous cycle of activity to continue with contributions from scientists throughout the world.

47 See details, above n. 44, and B. Fedder, Marine Genetic Resources, Access and Benefit Sharing: Legal and biological perspectives (Abingdon, Routledge, 2013) (Fedder), 115-6.

48 Plant Treaty art. 9; C. Chiarolla, S. Louafi and M. Schloen, 'An Analysis of the Relationship between the Nagoya Protocol and Instruments relating to Genetic Resources for Food and Agriculture and Farmers' Rights' in Morgera et al., above n.18.

Organization of African Unity model law https://www.wipo.int/edocs/lexdocs/laws/en/ oau/oauooien.pdf accessed 3 November 2019, art. 4, 8, 12, 14 in particlar art. 15 restricting use bio resource and the risks of loss of the ecosystem.

50 Plant Treaty, arts. 9, 13, 18; African model law art 21-6; C. Chiarolla, 'Right to food and intellectual property protection for plant genetic resources' in C. Geiger (ed.) Research Handbook in Human Rights and Intellectual Property (Edward Elgar 2015) 539-50; C. Guneratne, Genetic Resources, Equity and International Law (Edward Elgar 2012) 92-102; T. Adebola, 'Access and benefit sharing, farmers' rights and plant breeders rights: reflections on the African Model Law' 9(1) Queen Mary Journal of Intellectual Property (2019) 105-121 (Adebola), 106; Morgera, Need, above n. 42, 378-9.

51 Federal Agency for Nature Conservation and IUCN, 'A possible way forward' (2011) https:// www.bfn.de/fileadmin/MDB/documents/service/Skript_3o1.pdf accessed 3 November 2019 39-42.

52 Compare June 2019 draft ILBI n29 reflecting uncertainty, art 11.3 (a)(b). See also study 4 on how domestic measures address benefit sharing prepared pursuant to Conference of Parties of the Convention on Biological Diversity Decision 14/20 exploring some existing national requirements https://www.cbd.int/dsi-gr/2019-2020/studies/\#tab=1 accessed 30 November 2019 . 
Such a cycle would accord less reward and arguably a reduced incentive to the initial researcher (including investors in them and any related companies). Yet in addressing ABNJ there have been calls for more ambition and a focus on nature and the climate. ${ }^{53}$ From this starting point, and reflecting the points made above challenging a exclusivity-based approach, this contribution will explore some pathways to bring about a more open and also more sustainable approach.

\section{The Need to Have Ecosystem and Ecological Perspectives}

Conservation and sustainable use, included in the title of the ILBI, have ecological dimensions. ${ }^{54}$ Ecosystems undergo constant evolution. Populations of species (which include MGR) are components of larger ecosystems, and ecosystems interact with other species and the non-living environment, contributing to the functioning of that larger ecosystem and its living components. ${ }^{55}$ An ecosystem's resilience - its ability to retain its structure and functions in the face of disturbance - can be impaired by human and natural stressors, which could render it a simpler ecosystem, less able to support a high diversity of species. ${ }^{56}$ Warning signs currently abound that all ecosystems are under threat. Climate change is taking place against a backdrop of significant and accelerating

53 A.Vaughan, 'David Attenborough on climate change "We cannot be radical enough"' (New Scientist 9 July 2019) https://www.newscientist.com/article/2209126-david-attenboroughon-climate-change-we-cannot-be-radical-enough/ and David Attenborough documentary, 'Climate Change - the Facts' (May 2019) https://www.bbc.co.uk/programmes/ mooo49b1 https://www.bbc.co.uk/news/entertainment-arts-47988337 all accessed 29 October 2019 and Pacific Islands Forum, 'Forum Calls for Increased Level of Ambitions in New BBNJ Treaty' https://www.forumsec.org/forum-calls-for-increased-level-ofambitions-in-new-bbnj-treaty/ accessed 2 November 2019.

54 J. M. Blair, S. L. Collins and A. K. Knapp, 'Ecosystems as Functional Units in Nature' 14 Natural Resources and Environment (2000) 150; F. S. Chapin III, P. A. Matson and P. Vitousek, Principles of Terrestrial Ecosystem Ecology (2nd ed, Springer, 2011), 3-22.

55 S. A. Levin, 'Ecosystems and the Biosphere as Complex Adaptive Systems' Ecosystems (198) 431; G. Harris, Seeking Sustainability in an Age of Complexity (Cambridge, Cambridge University Press, 2007), 19-26.

56 C. Folke, 'Resilience: The Emergence of a Perspective for Social-Ecological Systems Analyses'16 Global Environmental Change (2006) 253, 257, 557, 570-1; C. S. Holling, 'Understanding the Complexity of Economic, Ecological and Social Systems' 4 Ecosystems (2001) 39o; R.Biggs, G. D. Peterson and J. C. Rocha, 'The Regime Shifts Database: A framework for analysing regime shifts in social-ecological systems' 23 Ecology and Society (2018) 9. 
global ecological degradation, ${ }^{57}$ with biodiversity loss equivalent to an extinction event ${ }^{58}$ and other changes in planetary conditions such as ocean acidification at unprecedented levels. ${ }^{59}$ The message of a 2019 report was that "nature and its vital contributions to people, which together embody biodiversity and ecosystem functions and services, are deteriorating worldwide". ${ }^{60}$

Accordingly, any use of MGR needs to interact with simultaneous efforts to reduce pressures on ecosystems. There should be a more visible, central place for regard to impact on ecosystems when working with MGR in addressing societal needs or commercial opportunities and in sharing the resulting benefits. ${ }^{61}$ The June 2019 draft negotiating text for the $\mathrm{IGC}_{3}$ does display awareness of this issue. It includes a suggested provision in the general principles requiring all States to "[a]pply an approach that builds ecosystem resilience to the adverse effects of climate change and ocean acidification and restores ecosystem integrity'62 Such a provision could support regard to delivering resilience in the ILBI.

The first possible element of an ecological and ecosystem focussed approach would be for the ILBI to reflect current scientific practice, and its likely development, by engaging with MGR in a digital form. This would limit, to an extent, the need for physical samples.

\section{5}

\section{The Meaning of MGR}

The traditional starting point for relevant MGR activity was "in situ" - actually finding and working with the physical raw materials in ABNJ. Samples would then be taken to land where more work was done. There is a deep scientific

57 Millennium Ecosystem Assessment, Ecosystems and Human Well-being: Synthesis (Washington DC, Island Press, 2005); World Wildlife Fund, Living Planet Report 2018: Aiming Higher (World Wildlife Fund, 2018).

$5^{8} \mathrm{~J}$ Rockström et al., 'Planetary Boundaries: Exploring the Safe Operating Space for Humanity' 14 Ecology and Society (2009) 32.

59 International Geosphere-Biosphere Programme, Ocean Acidification Summary for Policymakers, (2013, Report from the Third Symposium on the Ocean in a High-CO2 World, Stockholm).

6o IPbes, 'Global Assessment Report on Biodiversity and Ecosystem Services' IPbEs/7/10/ Add.1 p. 3 Key message A.

61 See further on this theme across the ввNJ and more widely, V. De Lucia, 'The Ecosystem Approach and the ввNJ Negotiations' (Working Paper 10 July 2019), available at SSRN: https://ssrn.com/abstract=3420988 or http://dx.doi.org/10.2139/ssrn.3420988 accessed 2 November 2019 and O. Woolley, Ecological Governance. Reappraising Law's Role in Protecting Ecosystem Functionality (Cambridge, Cambridge University Press, 2014).

62 June 2019 draft ILBI, above n. 29, art. 5(b). 
cultural norm of samples being stored in respositories, say in oceanographic institutes or in museums such as the Natural History Museum in London. Working with MGR in these repositories can be termed "ex situ". ${ }^{63}$ In theory, these materials are available for all to visit and use, consistent with the farming and stewarding analogy. In reality, lack of human resources, record keeping and taxonomic challenges (such as uncertainty as to whether this MGR is a species which has already been identified) has meant that not as many benefits are being taken from these MGR as would be desirable. ${ }^{64}$

Developments in chemistry, bioinformatics and computer science have created new opportunities for working with MGR. ${ }^{65}$ Physical samples can be analysed and the genetic data (e.g., a short and unlikely unique example would be ATTCGTAAGC) established from individual organisms, metagenomes established from an assemblage of microorganisms such as planktonic species, or chemical structures of derivatives identified such as proteins and metabolites. ${ }^{66}$ This genetic information could then be shared ${ }^{67}$ in online databases such as the National Center for Biotechnology Information (NCBI, operated from the United States). ${ }^{68}$ This would enable wider dissemination without access to the physical MGR, and the genetic information could be the subject of further research and synthetically used and modified, possibly leading to new commercial products - if, as ever, there is sufficient time and money.

In the past, the DNA was obtained on shore in a laboratory or on the research vessels after physical samples had been preserved. At the time of writing, however, DNA extraction and sequencing devices have been developed which float or sit on the seafloor. Examples are the MesoBot and devices using Oxford Nanopore sequencing systems. ${ }^{69}$ Such products can be used to deliver enough

63 See discussion in Kate/Laird, above n.10, 3.6.2.

64 See M. Rabone et al., 'Access to Marine Genetic Resoruces (MGR): Raising Awareness of Best-Practice Through a New Agreement for Biodiversity Beyond National Jurisidiction (BBNJ)' 12 Frontiers in Marine Science (2019) 520 https://doi.org/10.3389/fmars.2019.00520 (Rabone).

65 Morgera, Fair and Equitable, above n. 42, 67-71.

66 See e. g., M. E. Watanabe, 'The Nagoya Protocol: The Conundrum of Defining Digital Sequence Information' 69(6) BioSciences (2019) 480; T. E. Berry, B. J. Saunders, M. L. Coghan, M. Stat, S. Jarman, A. J. Richardson et al., 'Marine environmental DNA monitoring reveals seasonal patterns in biodiversity and identifies ecosystem responses to anomalous climatic events' 15(2) PLoS Genet (2019) e 1007943.

67 Rabone, above n. 64.

68 See website https://www.ncbi.nlm.nih.gov/ accessed 2 November 2019.

69 See Woods Hole Oceanographic Institution, 'Mesobot' https://www.whoi.edu/whatwe-do/explore/underwater-vehicles/auvs/mesobot/ accessed 2 November 2019, Oxford Nanopore Technologies https://nanoporetech.com accessed 22 November 2019. 
information for scientists to then replicate DNA sequences in the laboratory and use them as the base for further research and commercial development, without the need for the physical sample at all. This process would also involve additional significant work, as this in situ analysis would only give unassembled sequence data. The data needs to be assembled to a high degree of accuracy to begin the process of annotation to ascribe function to genes and this may require laboratory work and access to other annotated gene sequences.

Looking forward, it is likely that there will be more in situ sequencing through the advent of next generation sequencing technologies and practices. The use of these technologies in situ, and their implications, will need to be considered as part of the environmental impact assessment framework being developed elsewhere in the ILBI. ${ }^{70}$ Part of this will be the fact that these technologies could remove the need for raw materials to be collected, which would in turn reduce the scale of the environmental impact and ecosystem impact. ${ }^{71}$ Accordingly, the ILBI should cover data representing MGR samples from $A B N J$, as well as the physical sample. ${ }^{72}$ If the ILBI does not, then the careful balances sought to be struck in it regarding benefit sharing will not apply to all MGR activity ${ }^{73}$ Some support for the inclusion of data has been put forward at the IGC s${ }^{74}$ and the issue is included as a possibility in the June $2019 \mathrm{draft}$ ILBI, with definitions of MGR as "in silico", "[digital] [genetic] sequence data and [and information]". ${ }^{75}$ Engaging with digital information in the ILBI would also align with the view that MGR should be seen as natural information (even when in its physical form). This is because genes contain information about heredity and future possibilities for functionality (even though as noted detailed work is needed to move from this to important research and commercial

$70 \quad$ See June 2019 draft ILBI n29, arts. 22-41.

71 K. D. Prathapan, R. Pethiyagoda, K. S. Bawa, P. H. Raven, P. D. Rajan et al., Divakaran et al., 'When the cure kills - CBD limits biodiversity research: national laws earning biopiracy squelch taxonomy studies' 360 6395 Science Mag Policy Forum (2018) 1405 (Prathapan).

72 See also C. Lawson and M. Rourke, 'Open Access DNA, RNA and Amino Acid Sequences: The Consequences and Solutions for the International Regulation of Access and Benefit Sharing' 24Journal of Law and Medicine (2016) 96 (Lawson and Rourke) 11.

73 See Thambisetty, above n. 46.

74 See e.g., Earth News Bulletin 25.3.19 reporting on IGC 2: Caricom and Pacific Small Island Development States support the inclusion of resources, in situ, ex situ, in silio, digital sequence data and deriv, Turkey supports inclusion of digital sequence data.

75 June 2019 draft ILBI n29, arts 8 (2)(b) regarding application, 10(4) regarding access, 11(3) (a) and (b) regarding fair and equitable sharing of monetary and non monetary benefit, 13(3)(a) regarding monitoring, 42(c) (iii) regarding the objectives of capacity building and technology transfer and art 51(3)(c) regarding the clearing house. There is also the option that the ILBI would not cover this at all, art. 8(3)(b). 
development), and there are calls for equal protection of the two forms of information. ${ }^{7}$

Existing benefit sharing regimes, notably Nagoya, focus on physical genetic resources, so the proposal made here raises the important issue of having dual regimes. The question of digital sequence information is, however, currently being discussed in multiple forums including at the Convention on Biological Diversity negotiations, ${ }^{77}$ although uncertainty remains as to what definition and approaches will be chosen. For now, the discussion of new technology for genetic sequencing in situ raises another issue - the approaches taken to IP rights and to trade secrets.

The Approach to IP and Trade Secrets

\subsection{Context}

Increased technological development can bring with it more private-sector involvement. This can bring with it greater desire for private control of the results of research. This may seem unusual or heretical to scientists accustomed to norms (developed particularly in the context of human genome sequencing) of sharing data before and after publication. ${ }^{78}$ Limiting access is, however, quite consistent with the values of property, immediate reward, and control, which are familiar to the commercial sector. This sector was also noted to have a role in developing natural products to address societal needs. Further, involving the commercial sector in the pipeline to develop new products (often termed bioprospecting) has led to the increased wider understanding of global

76 Muller, above n. 20 at $16,18,20-1,23$.

77 СвD, 'Digital sequence information on genetic resources' https://www.cbd.int/dsi-gr/ 2017-2018/ and Commission for Plant Genetic Resources For Food and Agriculture, 'Digital Sequence Information' http://www.fao.org/cgrfa/topics/digital-sequenceinformation/en/; wHo, 'Approach to Seasonal Influenza and Genetic Sequence Data under the PIP Framework', https://www.who.int/influenza/pip/8bAnalysis_Draft1_ 17Sep2018_EN_hyperlinks.pdf?ua=1. See also study 1 science-based fact finding study on the content and scope of digital sequence information prepared pursuant to Conference of Parties of the Convention on Biological Diversity Decision 14/20 https://www.cbd.int/ dsi-gr/2019-2020/studies/\#tab=1 accessed 30 November 2019.

78 Bermuda Principles 1996 and Report from Wellcome Trust meeting, 'Sharing data from large-scale Biological Projects: A System of Tripartite Responsibility' 2003 https://www. genome.gov/Pages/Research/WellcomeReporto3o3.pdf accessed 2 November 2019. Lawson and Rourke, above n. 72, 108. See also reflections of this in OECD Guidelines for the Licensing of Genetic Inventions 2005 http://www.oecd.org/sti/emerging-tech/ 36198812.pdf accessed 3 November 2019 . 
biodiversity as a whole. ${ }^{79}$ This has been invaluable as funding for surveying biodiversity in itself is often very hard to obtain.

But even with this private-sector interest, it would be unwise to move to the other extreme and create an environment in which the commercial sector has too much power. This could have an overly negative impact on other scientific research, and on the benefits this other work could deliver ${ }^{80}$ and which could then be shared. ${ }^{81}$ Concern as the exercise and impact of private power has been seen in relation to human genes in the context of cloning (notably regarding the BRCA gene and expressed sequence tags), ${ }^{82}$ synthetic biology ${ }^{83}$ and, at a more downstream level, access to essential medicines. ${ }^{84}$

\subsection{Relevant Rights}

IP rights (notable ones being patents, copyright and trade marks) are held by private entities, pursuant to national legislation, in the context of an international treaty (TRIPS, 1994 under the WTO) which requires that WTO members have a system of IP rights. ${ }^{85}$ TRIPS also requires protection of confidential

79 See e.g., R. J. Quinn, P. de Almedia Leone, G. Guymer and J.N.A. Hooper, 'Australian biodiversity via its plants and marine organisms. A high-throughput screening approach to drug discovery' 74(4) Pure Appl. Chem. 2002, 519-526; NatureBank at Griffith University https://www.griffith.edu.au/institute-drug-discovery/unique-resources/naturebank accessed 2 November 2019 .

$80 \quad$ Prathapan, above n. 71, 1406.

81 C. Salpin and V. Germani, 'Patenting of research results relating to genetic resources from areas beyond national jurisdiction: The crossroads of the law of the sea and intellectual property law' 16(1) Review of European community and international environmental law (2007) 12-23 (Salpin and Germani), 16.

82 G. Matthijs and G-J B. Van Ommen, 'Gene patents: from discovery to invention. A geneticist's views' 311 (Matthijs and Van Ommen) and G. Van Overwalle, 'Of thickets, blocks and gaps' (Overvalle Thickets) 383, 453 both in G. Van Overwalle (ed.) Gene Patents and Collaborative Licensing Models: Patent Pools, Clearinghouses, Open Source Models and Liability Regimes (Cambridge, Cambridge University Press, 2009) (Overwalle); Nicola Lucchi, The Impact of Science and Technology on the Rights of the Individual (New York, Springer, 2016) (Lucchi) 99-103, 114-134, 141-162.

83 A. MacLennan, Regulation of Synethic Biology: BioBricks, BioPunks and BioEntrepreneurs (Cheltenham, Edward Elgar, 2018), 251 et seq.

84 H. Hestermeyer, Human Rights and the WTO. The Case of Patents and Access to Medicines (New York, Oxford University Press, 2007) chapters 1 and 4; F. Abbott, 'Managing the Hydra: The Herculean Task of Ensuring Access to Essential Medicines' 393; and H. Klug, 'Comment Access to Essential Medicines - Promoting Human Rights over Free Trade and Intellectual Property Claims' 481 in K. E. Maskus and J. H. Reichman (eds.) International Public Goods and Transfer of Technology Under a Globalized Intellectual Property Regime (Cambridge, Cambridge University Press, 2005).

85 Annex IC of Marrakesh Agreement Establishing the World Trade Organization (1994) 1867 UNTS 154 (TRIPS), in particular art 9, 27. 
information ${ }^{86}$ and this is delivered in national laws as a mix of legislation and case law. ${ }^{87}$ IP and trade secrets confer private power (with respect to IP rights for a limited period) over the results of innovation and creativity and over information if criteria are met for them to exist. In addition to the mandatory legal bases just mentioned, there are longstanding legal, economic and societal views in support of IP and trade secrets. Broadly, and reflecting some of the points made so far in this chapter, these are that IP rights and trade secrets encourage and reward innovation, and investment in it, to develop products for the benefit of all - and in the case of IP rights ensure disclosure of it, such that ultimately, there can be wider and unrestricted use of the innovation. ${ }^{88}$ So legally, and from an incentive perspective, the existence of IP rights and trade secrets, and their power, should not be ignored.

States can and do, however, impose some limits on the power held by IP owners and on controllers of secret information. The key issue here is the extent to which the ILBI can and should impose obligations on states to do this to ensure that benefit sharing can come about. IP has long been seen as potentially having some place in the ABNJ MGR process. In 2007 the UN SecretaryGeneral's report on Oceans and the Law of the Sea engaged with the work of the World Intellectual Property Organization (WIPO) on genetic resources regarding access and benefit sharing, disclosure of the origin of genetic resources and the links between this and the patent examination process to establish novelty - which is a necessary requirement for a patent to be granted - and also on the sharing of benefit. IP rights were included in the terms of the Working Group and information on IP was put before it. ${ }^{89}$ The "President's Aid to

\section{TRIPS, above n. 85, art. 39 .}

87 E.g., in England and Wales/ EU Coco v AN Clark [1968] FSR 415, EU Directive 2016/943/ EU on the protection of indisclosed know know and business information OJ L 157/1 16 June 2016.

88 Lucchi, above n. 82, 10; Heafey, above n. 16, 502; F M Scherer, 'The Innovation Lottery' in R. C. Dreyfuss, D.L. Zimmerman and H First Expanding the Boundaries of Intellectual Property. Innovation Policy for the Knowledge Society (eds.) (Oxford, Oxford University Press, 2001); K. E. Maskus, 'The Economics of Global Intellectual Property and Economic Development: A Survey' in P. Yu (ed.) Intellectual Property and Information Wealth (Westport, Praeger, 2006); C. Greenhalgh and M. Rogers, Innovation, Intellectual Property and Economic Growth (Princeton, Princeton University Press, 2010); Commission on Intellectual Property Rights, 'Integrating Intellectual Property Rights and Development Policy' (2002) http://www.iprcommission.org/ accessed 30 October 2019.

89 C. Chiarolla, 'Intellectual Property Rights Issues' Paper 6, IUCN Information Papers for Intersessional Workshop on Marine Genetic Resources 2-3May2013 (Chiarolla IUCN), 37 https:// www.un.org/Depts/los/biodiversityworkinggroup/documents/IUCN\%2oInformation\%2O Papers\%2ofor\%2oBBNJ\%2oIntersessional\%2oWorkshop\%2oon\%20MGR.pdf accessed 2 November 2019. 
Discussions" for IGC1 asks whether the relationship between the ILBI and IP should be set out and if so how; 90 the "President's Aid to Negotiations" for ${ }_{1 G C 2}{ }^{91}$ and the June 2019 ILBI draft for IGC include several options on IP, although they are restricted to patents ${ }^{92}$ and have a focus on disclosure of origin.

This contribution will not address this issue further, however it raises an important perspective. There has been some reluctance at the IGC to engage with patents and disclosure of origin on the basis that patents were dealt with in other international fora. ${ }^{93}$ Yet from the practical side, it has been clear in WIPO documents (including a 2019 draft from the chair) that it is not proposed that the outcomes will engage with resources from beyond national jurisdiction ${ }^{94}$ and attempts to discuss the issue within TRIPs have stalled. ${ }^{95}$ There are also more IP issues which should be raised in the ILBI, and failing to engage with them could lead to outcomes which are explicitly or implicitly more supportive of private sector control of MGR. ${ }^{96}$ Further, engaging with IP in the ILBI would be consistent with an established body of scholarship and policy making which seeks to avoid fragmentation of legal regimes. ${ }^{97}$ Indeed, the draft

$90 \quad$ PAD A/CONF.232/2018/3 25 June 2018 3.2.3.

91 PAN 3 December 2018 A/CONF.232/2019/1*3.2.3 and IUCN Commentary on June 2019 draft ILBI https://www.iucn.org/sites/dev/files/iucn_comments_on_bbnj_draft_text_august_2019.pdf accessed 2 November 2019 (IUCN Commentary) p. 18, 19.

92 June 2019 draft ILBI, above n. 29, art. 12.2, 12.3, 12.4 and IUCN Commentary, above n. 91, p. 19 regarding risks of the ILBI being inconsistent with TRIPS regarding restrictions on approval of the grant of IP rights, in IGC 3 para 12.4 (c).

93 See e.g., Earth News Bulletin 25.3.19 from IGC 2 Caricom and PSIDS want a sui generis approach to IP; G77/ China, African Group, Iran, Tonga, Federated States of Micronesia, Turkey, PNG, Sri Lanka and Cuba want IP included in the ILBI; Singapore want IP to be addressed in in existing mechanisms at WIPO and wTO; the EU, Canada, US, Switzerland, Norway, the Holy See, Japan, Korea, the Russian Federation, and Australia do not support IP rights being in the ILBI.

94 WIPO/GRTKF/IC/28/4 (2014), art. 4.1(e); WIPO/GRTKF/IC/3O/4 2016, art 3.1(e); WIPO/ GRTKF/IC/34/4 2017, art. 4(1)(e); draft report prepared by Chair of WIPO IGC on IPGRTKF 30 April 2019.

95 See wTо review of art 27.3 (b) https://www.wto.org/english/tratop_e/trips_e/art27_ 3b_e.htm accessed 22 November 2019 and proposals for new article 29 bis $\mathrm{TN} / \mathrm{C} / \mathrm{W} / 59$ of 2011. See also valuable discussion in C. Chiarolla, 'Intellectual Property from a Global Environmental Law Perspective: Key lessons from the implementation of patent disclosure requirements for genetic resources and traditional knowledge' Benelex Working Paper No 22 (Chiarolla Benelex) exploring whether requiring action is introducing another substantive requirement which is not clearly mandated under TRIPS, or or whether it is more of a procedural point therefore raising questions for the Patent Co-operation Treaty.

96 Salpin and Germani, above n. 81, 12-3.

97 L. R. Helfer, 'Regime Shifting: The TRIPs Agreement and the New Dynamics of International Intellectual Property Law Making' 29 Yale Journal of International Law (2004) 1; Morgera, Fair and Equitable, above n. 42, 58-9; G. Teubner and P. Korth, 'Two 
ILBI already includes, as noted, a proposed engagement with climate change which has its own regime. ${ }^{98}$ So the fact that an issue could be addressed in other regimes should not mean that it should not be considered in the ILBI. From this starting point, the next section will explore other means by which IP rights could impose obstacles to benefit sharing; will identify opportunities to resolve this from within IP law; and will suggest how these points could be addressed within ILBI. These proposals will be consistent with, and also move beyond the suggested, less specific, wording in the draft ILBI, so that it is to be applied in a manner which respects the competences of relevant legal instruments and does not undermine them, ${ }^{99}$ and so that it promotes coherence with those instruments, providing they are supportive of and do not run counter to the objective of UNCLOS and the ILBI. ${ }^{100}$

\subsection{Patents}

Firstly, there is an issue about the extent to which patents could be and are being granted over subject matter which is too close to MGR in its original form rather than, as is inherent in Mare Geneticum, M GR being the subject of innovation and transformed. Such patents would mean that there was private control over a fundamental natural resource from the very start. Others could then only use this with the consent of the patent owner, and this could reduce the innovation of these others in developing new commercial products and engaging in research. ${ }^{101}$ There is uncertainty about present practices in this respect. Analysis of patents identifies references to $\mathrm{MGR}^{102}$ with examples involving

Kinds of Pluralism: Collision of Transnational Regimes in the Double Fragmentation of World Society' in M. A. Young (ed.) Regime Interaction in International Law: facing fragmentation (Cambridge, Cambride University Press, 2012) 24, 41 with relevant challenges identified in conflicts between traditional approaches to confidentiality of indigenous groups and bringing about free use of information. For benefit sharing and farmers' rights outside the ABNJ, see C. Benelex, above n. 95, section 6 and Adebola, above n. 5o, 112.

98 United Nations Framework Convention on Climate Change 19921771 UnTs p. 107, which arose from the Earth Summit as did the Convention on Biological Diversity.

99 June 2019 draft ILBI, above n. 29, art. 4(3) first part.

100 June 2019 draft ILBI, above n. 29, art. 4(3) second part.

101 Chiarolla IUCN, above n. 89, 40; Chiarolla, above n. 44, 178-9; Heafy, above n.16, 520-1.

102 Chiarolla, above n. 44, 177; P. Oldham, 'WIPO Patent Landscape report Marine Genetic Resources' (2019) https://www.wipo.int/edocs/pubdocs/en/wipo_pub_947_6.pdf accessed 2 November 2019 looking beyond patents to publications, and funding sources and species, though a data mining approach, exploring 391,191 scientific publications and 461,38o patents, data from Global Biodiversity Information Facility; R Blasiak, J-B. Jouffray, C.C.C. Wabnitz, E. Sunstrom and H. Osterblom et al., 'Corporate Control and global governance of marine genetic resources' Sci Adv 2018 exploring the ownership of patents. 
Green Fluorescent Protein, ${ }^{103}$ red algae ${ }^{104}$ and sea cucumbers. ${ }^{105}$ The mere existence of such patents does not mean, however, that the right to control covers the MGR itself. There is a need for detailed analysis of the substance of patents, moving beyond data mining and empirical reviews of the landscape, to establish the extent to which this is so. Patents over raw MGR should not in theory exist, as patents must be new and inventive, without excluding patents capable of industrial application. ${ }^{106}$ The June 2019 ILBI draft included the valuable proposal that there shall be no patenting except when the MGR modified by human intervention results in a product capable of industrial application. ${ }^{107}$

This contribution develops this point in a new direction: in addition to clarifying when patents could be obtained, the ILBI could limit the power conferred by states. TRIPS provides that states can impose such restrictions on the rights of the patent owner, as long as they are limited, do not unreasonably conflict with a normal exploitation of the patent and do not unreasonably prejudice the legitimate interests of the patent owner, taking into account the legitimate interest of others ("the three step test"). ${ }^{108}$ Given this, and the research issue identified above, the ILBI could provide that states should provide in their national laws that research must be able to be continued in relation to an MGR innovation which is the subject of a patent. It is also suggested that the ILBI should provide that states are to impose this limit even if research is done for commercial purposes or by a commercial entity. This is because there is diversity across national laws regarding the scope of research exceptions regarding commercial activity. ${ }^{109}$ The approach would also remove uncertainties about

103 Jellyfish green fluorescent protein expression in plants WO199602765A1 (1996); B Verberue, 'Patent pooling for gene-based diagnostic testing' in Overwalle, above n. 82, 18.

104 Breeding method of high-temperature-resistant stichopus japonicus strain (2016 CN106259067A; CN106259067B - China), which has led to product development by LBD Marine Technology, 'About Agar' http://en.libangda.com/products-and-service/aboutagar/about-agar\#bit_olwy3 accessed 2 November 2019.

105 Preparation method of marine bacteria-derived kappa-carrageenase gene and recombinase (2016 - CN105950640A; CN105950640B - China) which has led to product development, see X. Ru, L. Zhang, 'Development strategies for the sea cucumber industry in China' 37(1) Journal of Oceanology and Liminology 2019 300-312.

106 TRIPS, art. 27(1); Chiarolla IUCN, above n. 89, 37-8.

107 June 2019 draft ILBI, above n. 29, art. 12.3 first sentence.

108 TRIPS, art. 3 .

109 Monsanto $v$ Stauffer [1985] RPC 515 and Auchinloss $v$ Agricultural \& Veterinary Supplies [1997] RPC 649 compare German approach Clinical Trials II [1997] NJW 3092; see analysis in F. Humphries, 'Shellfish patents kill experimentation: defences for sharing patented aquatic general materials in aquaculture' 37(4) European Intellectual Property Review (2015) 210-224, 213-4. 
what activities should properly be viewed as commercial. Non commercial activity could end up as commercial, in the immediate or longer term; ${ }^{110}$ those who may traditionally be perceived as non commercial actors (say those from universities) may be encouraged by their universities or may simply choose to set up their own companies to develop products while also seeking collaboration and community.111

TRIPS also provides that states can require sharing of patented innovation through a compulsory licence to respond to national emergencies. ${ }^{112}$ Given the discussion so far regarding the place of MGR-related innovation in responding to climate change, the ILBI should provide that states must include in their national laws compulsory licensing of patents with respect to energy transitions or ecologically sustainable products. TRIPS requires, however, that this licensing is in return for the payment of adequate remuneration. ${ }^{113}$ Given the complex arguments regarding the positive (as well as problematic arguments) regarding the power of IP rights and the need for investment, it is unlikely that in the present context this could mean zero. Adequate does not, however, mean the same as a full commercial market rate.

The next section will explore the place of other IP and trade secrets in benefit sharing with respect to MGR. This issue is not recognised, or at least not directly, in IGC debate and in official documents generated so far. It is suggested that this should be addressed and this point has been made in contributions by the authors to the commentary of the International Union on the Conservation of Nature on the June 2019 draft ILBI. ${ }^{114}$

\subsection{Database, Copyright and Trade Secret: Repositories 6.4.1 Problem}

This wider IP inclusion argument will be developed here in the context of databases and repositories, which were explored above, particularly in the context of digital sequences. At present, DNA sequence data can be deposited at one of 3 global databases - NCBI ${ }^{115}$ (in the United States, discussed above) under the term GenBank, European Bioinformatics Institute (EMBL - EBI,

\footnotetext{
110 Correa, above n. 8, 13-14.

111 Correa, above n. 8, 15-6.

112 TRIPS art. 31, in particular (b). This can also be argued to be necessary when there is no alternative e.g., Brigit Verberue, 'Patent pooling for gene-based diagnostic testing' in Overwalle n. 82, 17, 18, exploring Green Fluorescent Protein (see also n. 103) and also innovation in respect of rice and Huntingdon's disease.

113 TRIPS, art. 31(h).

114 IUCN Commentary, above n. 91, p 19.

115 See above n. 68.
} 
Europe $)^{116}$ and DDBJ (Japan). ${ }^{117}$ Together, these form the International Nucleotide Sequence Database Collaboration (INSDC) and they share all DNA sequence data on a daily basis. Each has different tools to interpret and process the data, meaning that data downstream from the DNA sequence will differ in each one of these in terms of format, content and processing. A pragmatic outcome regarding the future of repositories would be for the existing arrangements for collecting and sharing DNA to continue and develop, with the ILBI requiring an overall metadatabase. Within this, copyright ${ }^{118}$ (and also related rights, such as the database rights which exist in the EU) $)^{119}$ and trade secrets ${ }^{120}$ can, as will be seen, be relevant to the manner of operation of these and other databases and to the level of benefit sharing which can occur.

Copyright, database rights and trade secrets do not require a registration process to exist. For copyright to exist, there must be a work. An individual piece of data would not be enough, ${ }^{121}$ but there could be copyright in a report of a cruise or planned cruise with details of location and findings, as this would count as a literary work. ${ }^{122}$ Further, depending on national laws, copyright could exist with respect to a collection of smaller pieces of information which is original in the sense of not copied and reflecting skill, labour and judgment in its collection; ${ }^{123}$ in the EU member states a different test now applies, with the need for it to result from some intellectual creativity. ${ }^{124}$ For database rights to exist for a set of information, including a collection of DNA, there must be substantial investment in obtaining, verifying or presenting existing information. ${ }^{125}$ There will be a relevant trade secret if information is not in the public

116 See https://www.ebi.ac.uk/ accessed 2 November 2019.

117 See https://www.ddbj.nig.ac.jp/index-e.html accessed 2 November 2019.

118 For a wider introduction to copyright, see A Brown, S Kheria, J Cornwell, M Iljadica, Contemporary Intellectual Property: Law and Policy (5 ed.) (Oxford, Oxford University Press, 2019) (Brown), 31-203, 219-231.

119 For a wider introduction to database rights, see Brown, above n. 118, 238-251; EC Directive 96/9/EC on the legal protection of databases O.J. L 7711 March 1996 20-28 (Database Directive).

120 For a wider introduction to trade secrets, see Brown, above n. 118, 697-725.

121 Exxon Corporation v Exxon Insurance [1982] Ch 119 - no copyright in the word "Exxon".

122 TRIPS, art. 9 encompassing Berne Convention arts. 1 and 2.

123 For the traditional position in the UK, see Ladbroke $v$ William Hill [1964] 1 WLR 273, Interlego AG v Tyco Industries [1989] AC 217 compare US decision Feist Publications $v$ Rural Telephone Service Co 499 US 340 finding no copyright in alphabetical listng of names.

124 Infopaq International A/S v Danske Dagblades Forening C-5/o8 [2009] ECDR 16.

125 Database Directive, art. 7; British Horseracing Board v William Hill Organization Ltd Case C-203/O2 [2005] RPC 13. and Football Dataco Ltdv Sportradar [2013] EWCA Civ 27. 
domain, has value because it is secret and reasonable steps have been taken to make sure it is secret. ${ }^{126}$

Depending on the methods by which information is provided and stored on the repositories, the attitudes taken by the information supplier and the relevant national law, these three legal bases/rights could apply to material which the ILBI may state is to be in public databases or repositories. ${ }^{127}$ Finally, copyright will also exist ${ }^{128}$ (and indeed in some cases software patents may be granted $)^{129}$ over the software which actually operates the databases and repositories. In terms of impact, copyright confers the possibility of private control of the reproduction of the work containing the information; ${ }^{130}$ database rights control the extraction or re-utilisation of whole or substantial parts of contents of the database; ${ }^{131}$ trade secrets control the use of the information itself; 132 and copyright and patents over the database could control the ongoing method of operation. These rights could lead, then, to refusals to supply the information in the first place, to requests that there will be no onward disclosure without the making of a payment, or that the database can only continue with the payment of a fee..$^{133}$

There are suggestions that this is already a reality, with arguments regarding the Convention on Biological Diversity that key information is not being shared fully as it is the subject of confidentiality claims and that it is therefore difficult to assess whether fair and equitable benefit sharing is being delivered. ${ }^{134}$ Further, reflection on some existing databases and repositories with respect to DNA confirms that IP related issues could arise. ${ }^{135}$ Careful analysis of existing genetic resources databases has explored arrangements which

126 TRIPS, art 39(2); Coco v Clark, above n. 87; Trade Secrets Directive, art 2(1).

127 Chiarolla, IUCN, above n. 89, 42; Chiarolla, above n. 44, 184; Lawson and Rourke, above n. 72,116 .

128 TRIPS, art 10.

129 Lawson and Rourke, above n. 72,116. For a wider introduction to this complex issue and the different approaches taken across countries, see Brown, above n. 118, 435- 465 and in particular Re Bilski 545 F $3 \mathrm{~d} 943$ and Alice Corporation v CLS Bank International 572 US 208; Symbian v Comptroller General of Patents Designs and Trademarks [2008] EWCA Civ 1066; Go3/93 Programs for Computers [2010] E POR 36.

130 See e.g., UK Copyright Designs and Patents Act 1998, s16(1)-(3).

131 See e.g., UK Copyright and Rights in Database Regulations 1997 No. 3032 (implementing the Database Directive) 12(1).

132 Coco v Clark, above n. 87; Trade Secrets Directive, arts. 3, 4.

133 Fedder, above n. 47, 119-120.

134 Muller, above n. 20, 33, 39-4167.

135 Chiarolla, above n. 44, 183; Lawson and Rourke, above n. 72, 103. 
database operators have chosen to take to IP and trade secrets ${ }^{136}$ and has identified strong themes of sharing across publicly funded databases. Yet in this landscape there is also a place for IP. The terms and conditions of NCBI's GenBank provide that material which is uploaded to GenBank may be the subject of IP rights although no restrictions are imposed on further use of information which is uploaded. ${ }^{137}$ The combined INSDC has a policy of free and unrestricted access to the records in their databases. ${ }^{138}$ Looking more widely, the BioBricks Initiative involves standard interchangeable DNA parts that have defined functions and that can be used in the construction of synthetic biology systems. Its goal is for "all genes and vectors that are synthesized and distributed through the rok genes project [to] be solidly in the public domain and free of third-party rights" ${ }^{139}$ Further, BioBricks makes genes available free of charge and checks that they are not the subject of sequence-specific patent claims. ${ }^{140}$ Yet BioBricks' terms and conditions provide that if IP rights exist then they are to be respected and that if submissions to it are the subject of IP rights, then the details of this are to be provided. ${ }^{141}$

The above discussion reveals some wide embracing of sharing but also alongside it instances of models with an embedded respect for IP rights. Further, the sharing approach - which is so positive for science - cannot be relied upon to continue. Funding arrangements may come to an end, ${ }^{142}$ government

136 C. Lawson, H. Burton and F. Humphries, 'The important place of information in the evolving legal and policy framework for the conservation and sustainable use of the world's plant genetic resources for food and agriculture' EIPR 2018 4O(4), 243-259, 247, 249-50, 251, 253, 255-6 and table 1; Lawson and Rourke, above n. 72, 100-2, 104, 111-2; see also study 3 Combined Study on Digital Sequence Information in Public And Private Databases and Traceability prepared pursuant to Conference of Parties of the Convention on Biological Diversity Decision 14/20 exploring some existing national requirements CBD/DSI/ AHTEG/2020/1/4 31 January 2020.

137 See webpage 'GenBank submission types' https://www.ncbi.nlm.nih.gov/genbank/submit_types/ accessed 3 November 2019 .

138 INSD ‘Collaboration Policy' http://www.insdc.org/policy.html accessed 3 November 2019 rules $1-3$.

139 K. Kendall, S. Pownall, L. Kahl, 'Bionet 1ok Genes Project Documentation vı.o' https:// www.reddit.com/r/bionet/comments/7bo7gz/bionet_1ok_genes_project_documentation_vio/ accessed 3 November 2019.

140 BioBricks Foundation, 'The Free Genes Project' https://biobricks.org/freegenes/ accessed 3 November 2019.

141 Ibid., 'Explanation' 1 bullet 3, 'Submission' 1 bullet 2.

142 See e.g., the journey of the Arabidopsis Information Resource - funded by National Science Foundation, then the core staff group set up Phoenix Bioinformatics (not for profit) to subscription offering with different levels of access, all made available after one year https://www.arabidopsis.org/. For an example of a subscription database, see Marinlit http://pubs.rsc.org/marinlit/ both links accessed 3 November 2019. 
policy may change regarding support of service, or a private provider may provide software to the database and then choose to take a new approach.

\subsubsection{Solution}

In the light of this, the ILBI should focus on the sharing and disclosure requirement of the suggested metarepository. ${ }^{143}$ There has been some engagement with the issue, albeit without a focus on the underpinning legal issues just discussed. Calls have been made for databases to be open ${ }^{144}$ and there are references in the June $2019 \mathrm{draft}^{145}$ for "a clearing house mechanism with a web based platform to provide open access to MG R". ${ }^{146}$ The draft ILBI also suggests, however, that due regard is to be had to the confidentiality of information being provided to the platform. ${ }^{147}$

Building on the discussion above, this suggests that information provided could be incomplete. Further, there are a variety of positions regarding the meaning of "open access". ${ }^{148}$ To a lawyer the word may suggest immediately available, for no fee - just as seen (up to a point) in relation to BioBricks. This approach to open access is used in the context of licensing models ${ }^{149}$ which IP owners have chosen to embrace like CAMBIA Bios, ${ }^{150}$ Creative Commons ${ }^{151}$ and the Eco-Patent Commons (which is now closed). ${ }^{152}$ These all provide specific licensing terms or conditions of use (for example, approaches taken to commercial use or acknowledgement) and have no licence fee. These frameworks operate on a voluntary level, however, so in this sense they do not deliver a base for a mandatory ILBI approach. It should also be borne in mind that

143 See discussion on this issue in Chiarolla, IUCN, above n. 89, 41-2, 43; Chiarolla, above n. $44,181-3$.

144 Fedder, above n. 47,122-176; Rabone, above n. 64.

145 June 2019 draft ILBI n29, art. 51, 51.2, 51.7.

146 See previous discussion in Leary, above n. 30, 21-29 and June 2019 draft ILBI n. 29, art. 11.3 (b).

147 June 2019 draft ILBI, above n. 29, art. 51.7 and IUCN Commentary, above n. 91, p 6o.

148 See IUCN Commentary, above n. 91, pp. 17, 59.

149 E. van Zimmeren, 'Clearinghouse mechanisms in genetic diagnosis' in Overwalle, above n. $82,71-9$.

150 See http://www.copyleftlicense.com/licenses/cambia-plant-molecular-enablingtechnology-bios-license-version-15/view.php accessed 3 November 2019; N. Berthels, 'Case 8. CAM BIA's Biological Open Source Initiative (BiOS)' in Overwalle, above n. 82.

151 See https://creativecommons.org accessed 3 November 2019.

152 See CEF Spotlight, 'Welcome to the Eco-Patent Commons' http://www.corporateecoforum.com/welcome-to-the-eco-patent-commons/ accessed 29 October 2019. Note debate about the value of the patent made available - B. H. Hall and C. Helmers, 'Innovation and diffusion of clean/green technology: Can patent commons help?' 6(1) Journal of Environmental Economics and Management (2013) 33-51. 
"open access" can have a different meaning for scientists. The focus there is not on IP and payment, but on ensuring that the database provides the necessary information for scientists and interoperability with other databases, publications and networks. ${ }^{153}$ Finally, the term "open access" can have a cultural meaning in terms of delivering fairness, equity and community sharing. This can be seen in the Floss (Free Libre and Open Source) Movement, which is deeply opposed to property rights and control. ${ }^{154}$

Debate, and ultimately clarification, is therefore needed on this point in the ILB I. If one wished to require fee-free access, IP and trade secrets issues could arise. ${ }^{155}$ This is because requiring that the control conferred by IP rights and trade secrets could not be relied upon, could move beyond the relevant flexibilities within TRIPS. ${ }^{156}$ TRIPS has no national emergency provision regarding copyright and trade secrets. The proposal made above regarding patents could be adapted to cover patents over relevant software used by international metarepositories. A version of the three-step test applies, however, to copyright. ${ }^{157}$ It could be argued again that fee-free access ${ }^{158}$ was too much of an interference with the power of the right and could be a disincentive for the development of valuable and needed software. A solution could be to require mandatory sharing with a reasonable payment to be made to the owner of the copyright or database right. ${ }^{159}$ This could also build on arguments that IP rights can be seen not as a right to exclude but as a right to payment,, ${ }^{160}$ or as a right to distribute and bring about uses of technology. ${ }^{161}$ To ensure that the payment can be made while also maximising the needs of benefit sharing and science,

\footnotetext{
153 Rabone, above n. 64.

154 See GNU Operating System at https://www.gnu.org/philosophy/floss-and-foss.en.html accessed 3 November 2019. A. S. Taubman, 'Several kinds of 'should" (Taubman) 223 in Overwalle, above n. 82 .

155 These issues were raised in IUCN Commentary in the context of clearing houses and check points, above n. 91, p. 20.

156 Building on points made in Chiarolla, above n. 44, 175-8.

157 See above n. 106, 108, 112-3 122; TRIPS, art 9, encompassing Berne Convention, art 9(2).

$15^{8}$ For other possibilities, see E. van Zimmeren, 'Clearinghouse mechanisms in genetic diagnosis' in Overwalle, above n. 82, 63, 68; Chiarolla, above n. 44, 190-1.

159 See also S. Dusollier, 'The commons as a reverse intellectual property' in H. Howe and J. Griffiths (eds.) Concepts of Property in Intellectual Property Law (Cambridge, Cambridge University Press, 2013) (Howe and Griffiths) 265-6 267, 268 seeing the role of exceptions to copyright as creating a functional public domain.

160 D. L. Burk, 'Critical analysis: property rules, liability rules and molecular futures. Bargaining in the shadow of the cathedral' in Overwalle, above n. 82.

161 Taubman, above n. 154, at 225, 226-7, 233, 239; D. Lametti, "The concept of the anticommons. Useful, or ubiquitous and unnecessary?' in Howe and Griffiths, above n. 159, 251-2.
} 
the ILBI could provide that these payments received could be passed on by the IP owner to the biodiversity fund to enhance further activity. For those unable to pay, the fund could make the payments to the IP owner. This would also be consistent with arguments for a more stewardship approach to be taken to IP.. It has been argued that the "patent owner-as-steward is not asked to 'conserve' the subject matter of his property in the same way as the landowner is required to conserve the natural world under this model, but there is no reason why they should not be expected to take environmental concerns into account in exploiting the invention". ${ }^{162}$ The relevant environmental concerns here would be enabling the sharing of information about MGR and the enabling of further research which could, inter alia, contribute to ecologically sustainable development.

Trade secrets remain. TRIPS does not engage with defences to trade secrets. National laws do have established defences, notably in the United Kingdom, that use is in the public interest, ${ }^{163}$ and this is reflected to an extent in the EU Trade Secrets Directive. ${ }^{164}$ The inherent nature of trade secrets makes it a challenge, however, to construct a forward looking regime - defences can operate only in the context of a leak of information. The public interest defences could be a base for the ILBI requiring proactively that details are shared of information obtained on research cruises, as this would in turn enable further scientific research by others. This would also be consistent with obligations under UNCLOS for states to take steps to actively promote the transfer of information and knowledge resulting from marine scientific research. ${ }^{165}$ The issue remains, however, of the level of interference with the incentive to be involved in marine biodiversity research, particularly given the more measured suggestions seen to be needed regarding IP rights. The binary nature of trade secrets makes it difficult to introduce a solution based on exceptions to the right. It is suggested, then, that a period of secrecy can continue for a period (say 6-12 months), similar to the existing Mare Geneticum proposal in respect of exclusivity, and then the information must be made available to all. If there is disclosure of information within this initial period, there should be a defence if information is used to contribute to bringing about ecologically sustainable practices.

162 H. R. Howe, 'Property, sustainability and patent law' in Howe and Griffiths, above n. 159, 299 (quote), 298-300; Blasiak, above n. 15.

163 Attorney General v Observer Ltd [1990] 1 AC 109 involving diaries of a member of security services.

164 Trade Secrets Directive, art. 5 .

165 UNCLOS, art. 244. 


\subsubsection{Delivery}

The draft ILBI of June 2019 shows some willingness to engage with IP as it has an IP clause, albeit with a focus on patents. ${ }^{166}$ The more minimalist approach also remains (as also seen in the Aid prepared for IGC2), ${ }^{167}$ with the draft having suggested clauses providing that implementation of the ILBI is to be in a manner consistent with the WIPO and the WTO, or ensuring that IP rights are supportive of and do not run counter to the IBLI' s objectives. ${ }^{168}$ There is also the prospect of the parties choosing not to have an IP provision in the ILBI. Such an approach would bring about the fear expressed by some IGC delegates that if IP and MGR is not addressed in the ILBI, it may not be addressed anywhere. ${ }^{169}$ The position discussed at WIPO suggests that this may be so in respect of disclosure of origin. IP appears, however, to be moving more into the mainstream. At IGC3 in August 2019, there was a confidential informal meeting on the place of $\mathrm{IP}^{170}$ and there were a growing number of IP experts, ${ }^{171}$ as well as a side event co-ordinated by the authors exploring the possible place of IP. $^{172}$

The next section moves along the development and benefit sharing pipeline and evaluates how the use of MGR could be traced through IP and elsewhere.

Tracing

Patents and disclosure of origin are one form of doing this tracing. The focus here is more on the wider picture. The June 2019 draft ILBI refers to the possible assigning of an identifier to MGR collected in situ, ex situ, and digital sequence information. ${ }^{173}$ Concerns have been raised that tracing would be burdensome and costly and a deterrent to scientific activity. ${ }^{174}$ This is not

\footnotetext{
166 June 2019 draft ILBI, above n. 29, art. 12.

167 PAN 3 December 2018 A/CONF.232/2019/1*3.2.3 Options II and III.

168 June 2019 draft ILBI, above n. 29, art 12.1, 12.2 first section. See IUCN Commentary, above n. 91, p 18-19, calling for specific engagement with flexibilities under TRIPS.

169 Earth Negotiations Bulletin 25 (2019) 25 March 2019 "in corridors", noting intense talk on IP and benefit sharing and frustrations about IP shifting from place to place in a "merrygo-round" of intellectual property fora.

170 A/CONF.232/2019/8/Rev.1.

171 Personal view of the authors from their own experience.

172 See Schedule of side events: https://www.un.org/bbnj/sites/www.un.org.bbnj/files/bbnj_ igc_iii_side_events_schedule_final_eng.pdf accessed 3 November 2019, 22 August event 2, orgnaised by authors with IUCN and Deep Ocean Stewardship Initiative.

173 June 2019 draft ILBI n. 29, art. l1.3(3)(a) and see IUCN Commentary, above n. 91, p. 20.

174 See e.g., Earth Negotiations Bulletin 25 (2019) 25 March 2019 - Caricom wanted a nonintrusive track and trace system.
} 
necessarily so. ${ }^{175}$ There is existing technology through Global Positioning System data and use of digital object identifiers that would render tracing the journey of MGR along the scientific and commercial supply chain as both possible and best practice. Repositories can - and importantly already do - have an important role including in the allocation of identifiers. Further examples, in addition to those mentioned above, are ChemSpider ${ }^{176}$ and metadatabases such as Ocean Biographic Information System (OBIS). ${ }^{177}$ Each takes care of a different subset of the information and interlinks at different levels: they track MGR, taxonomy and publications (and also patents which are related to MGR) as part of established practice in sample management and scientific practice including through the requirements of funders and of journals. ${ }^{178}$ Looking forward, evolving technology, such as blockchain and distributed ledgers may enable information to be traced more readily. 179

So, a full technological solution would be possible to track and trace all MGR through the biodiscovery pipeline in its different forms. Yet this full solution is not yet available to all. There would be a need for existing practice to be made available globally, in a capacity building technology transfer effort, so that common standards for data can be shared fully. Work is ongoing on this already through овIs through the Darwin Core Archive. ${ }^{180}$ Nonetheless, it is suggested that the ILBI should require a sample unique identifier and set out the functionality requirements which are to be delivered from time to time, with the method of this to be monitored through a new central body envisaged in the ILBI. ${ }^{181}$ The ILBI should not require the use of any particular product. The suggested functionality would not in fact make it possible to know where any MGR sample is at any given time or who is using a genetic sequence. The sample unique identifier would mean, however, that the sample can be to traced

175 Morgera, Fair and Equitable, above n. 42, 68-76; R. Wynberg and S. A. Laird, 'Fast Science and Sluggish Policy: The Herculean Task of Regulating Biodiscovery' 26(1) Cell Press Review Trends in Biodiscovery (2018) 1-3; M.A. Bagley and A. K. Rai, 'The Nagoya Protocol and Synthetic Biology Research: A Look at the Potential Impacts' Virginia Public Law and Legal Theory Research Paper No. 2014-o5 (2014); Chiarolla, Benelex, above n. 95, section 4; Lawson and Rourke, above n. 72, 116, 117 .

176 See http://www.chemspider.com/ accessed 3 November 2019.

177 See https://obis.org/ accessed 3 November 2019.

178 Lawson, Burton and Humphries, above n. 136; Rabone, above n. 64; see Database Study, above n. 136 .

179 Lawson, Burton and Humphries, above n. 136, 247-8, 259; see Database Study, above n. 136 .

18о See овіS webpage https://obis.org/manual/dataformat/ accessed 3 November 2019.

181 June 2019 draft ILBI, above n. 29, art 48 and in particular art 48(d)(i), art 49.1, 4 Alt1 (c). 
back to its origin, enabling payment into the biodiversity fund to be made from product sales or patent royalties.

The tracing and payment frameworks could fund the sharing of information and opportunities set out in this contribution, in addition to the payments which IP owners may choose to make to the biodiversity fund. This is important given that the International Nucleotide Sequence Database Collaboration (INSDC), has a combined annual global cost of US\$ $50-60$ million. ${ }^{182}$ The fund could also, as noted, make payments to IP owners if the research user is not able to do so. From this base, the next section will consider the range of the benefit sharing obligations. M GR and Benefit Sharing: Toward Future Proofing ${ }^{183}$

\subsection{Timing of Benefit Sharing}

As noted at the start of this contribution, Mare Geneticum raised the prospect of a period of exclusivity for the initial researcher, and this was seen to have been the subject of some criticism. It has been argued at the IGC that the ILBI should not condone or require a privatising approach to the samples. ${ }^{184}$ Further, a more open approach to sharing would be aligned with an emerging cultural approach in science and in data curation, and that information should be FAIR (findable, accessible, interoperable and reusable). ${ }^{185}$ Indeed, the proposals made above regarding metadatabases and sharing of information seek to deliver this later in the process.

It is suggested here that this mandatory sharing should apply from the start, with the requirement of exclusivity for the initial researcher set aside. It is suggested that making MGR samples (physical and digital) openly accessible from the start will be possible in many cases and if so, this should be done. With the physical sample, the collection may be limited depending on the amount

182 See Database Study, above n. 136.

183 IUCN Closing Statement for IGC 3 and see IUCN, 'Future-proofing protections for the high seas'(5 September 2019) https://www.iucn.org/news/marine-and-polar/201909/futureproofing-protections-high-seas accessed 3 November 2019.

184 Earth Negotiations Bulletin 25 (2018)12 September 2018 at IGC 1 arguments by PSIDS.

185 European Marine Biological Research Infrastructure Cluster (EMBRIC), 'ABS principles for preserving, accessing, exploring and sharing marine genetic resources' (April 2019), http://www.embric.eu/node/1759 accessed 3 November 2019; S. Stall et al., 'Make all scientific data FAIR' 570 Nature (6 June 2019) 27-29; H. Pierce et al., 'Credit data generators for data refuse' 570 Nature (6 June 2019) $33^{-}-32$. 


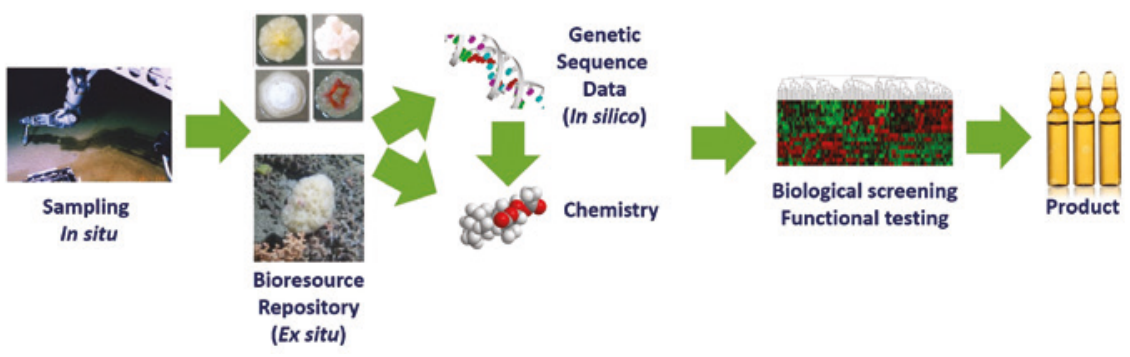

FIGURE 6.1 A simplified schematic showing the steps in the marine biodiscovery process. Sampling in situ is the first step, and this can be to collect a whole organism (such as a sponges or seacucumber) or a sediment which contains millions of microorganisms. A whole organism can be extracted to obtain bioactive compounds, or alternatively, pure microbial cultures are isolated from a marine sediment. These pure cultures can be grown at a larger scale to obtain bioactive compounds. In parallel, many studies now obtain genetic sequence data on organisms which allows the identification of what the organism might be able to produce. Eliciting the production of such compounds can be difficult as the factors needed to do this are not well understood. Extracts and pure compounds are subjected to biological screening (e.g., against cancer, infections or inflammation) or functional screening (e.g., as enzymes for washing powders or cosmeceuticals). Taking products to market can be a long and difficult process, as for pharmaceuticals, or it can be quicker for products for which regulation is less stringent.

which the scientists recovered from the research cruise - and from an ecological and ecosystem focussed approach, the samples removed should be as limited as possible. In such cases, it is proposed that the researchers that instigated the collection should be given the first chance to work on the limited physical samples. Given the points made in Mare Geneticum, it is hoped that this would include researchers from developing nations. When there is ample material collected, in a manner which means that it could be used in other projects, it is proposed that this should be shared between researchers for multiple non-competing research uses. This would reflect a practice used by the Norwegian Marine Biobank, MarBank. ${ }^{186}$ This approach would be efficient and equitable for the environment and for science. It would make the best use of existing materials, reduce the need to repeat collection and generate overlapping collections, and enable data to be acquired in parallel on the same sample, thus increasing knowledge of biodiversity (Figure 6.1).

186 See https://www.imr.no/marbank/en accessed 3 November 2019. 


\subsection{Scope of Benefit Sharing}

A second issue is when in the pipeline the obligations to share benefits that build on work with the MGR should end. Should the obligation only cover basic collection and genetic analysis? Should it encompass all research and development building on the MGR to any extent in its different forms? Should it extend to commercial activity ${ }^{187}$ which started with the MGR, modified the MGR, and/or which used products and research which had been based on work with the MGR? They may be a long way down a development pipeline away from the MGR, yet this phase of commercialisation could be said not to have been possible without the MGR.

The challenges of identifying what is commercial has already been seen above in respect of research. There is also the question of how far one should seek to gain benefit from, or indeed users should seek to recognise and repay, what they have gained from MGR - even if they have also added to it through significant financial investment, time and expertise. A later drawing of the line would mean that more activities would be subject to the benefit sharing regime. This could be objected to on the basis that by this time there would already have been a fair and equitable return to all from the earlier use made of the MGR and benefit sharing in respect of it.

When there is an IP right, it has been suggested, building on existing theories of "bounded openness", that there should be sharing of financial benefit in respect of the natural information discussed above. ${ }^{188}$ This draws not on the nature of the activity (such as commercial or non commercial, in or ex situ, physical or information) but on the fact that the MGR information does and should flow freely. This proposal then is that payments could be made, therefore, of a fixed royalty from the IP right into a fund, with the amount to depend, with echoes of Mare Geneticum, on utilisation levels and the industry involved. ${ }^{189}$ Alongside this, again with echoes of Mare Geneticum, this work proposes that details are to be shared of where the MGR was found so that the increased information will create more choice between useable MGR - which would lead in turn to more demand and also more cooperation, more complementarity and less overlap and so less damage to fragile ecosytems from activity. ${ }^{190}$

The draft ILBI of June $2019^{191}$ explored what activities would be covered by utilization of resources. Yet the location in the pipeline of the activities, and how

187 June 2019 draft ILBI n. 29, art. 1.15 varying approaches.

188 Muller, above n. 20, 24, 117.

189 Muller, above n. 20, 8, 66, 88.

190 Muller, above n. 20, 73-4, 77, 79 figure 5.1, 80.

191 IUCN Commentary n. 91, p. 7, art. 1.15 Alt 2. 
the work on MGR has been the subject of say second or third generation activity, has not been explored in the negotiations. IP rights will not always exist, so it is proposed that they should not be the base for a solution. Proposals made in the context of animal and plant breeding at the Convention on International Trade in Endangered Species of Wild Fauna and Flora limited regulation from this perspective to the first, second, third and fourth generations. ${ }^{192}$ This genetic perspective does not, however, map directly on to product development. The pharmaceutical products which are ultimately approved by regulators may have gone through 10 or so developments beyond the original MGR. It is suggested, therefore, that benefit sharing will only apply to the first three generations of a product by each innovator which are brought to market drawing on MGR. Issues could of course arise about innovators moving from one company to another and of businesses restructuring. For now, however, we consider that this provides a useful starting point.

\section{Delivering an IP-Based Ecosystem Approach to Benefit Sharing}

The final step of this contribution is to draw together, and enhance, the delivery of an ecosystem and ecological approach to benefit sharing. As noted, there could be compulsory licensing of patented inventions to deal with national emergencies which could include ecologically sustainable products in exchange for an adequate payment which could be paid into the diversity fund; an option for reasonable payments made for use of copyright and database works in relation to repositories to be paid into the diversity fund; and for use of secret information to pursue ecological goals to be covered by a public interest defence. This provision of some ongoing reward for the innovator and IP owner engages with one of the incentive strands set out at the start of this chapter. The sharing of the information and payments in some cases to the biodiversity fund to support activity by developing-country scientists engages with the second strand.

Further incentives could be included in the ILBI to encourage choices for MGR to be used to develop ecologically sustainable technologies rather than, say, other health treatments and cosmetics. "Ecologically sustainable technologies" could be defined by the central body likely to be established under the ILBI or through a new role given to an existing body. This could draw from work under the United Nations Framework Convention on Climate Change in respect of "environmentally sound technologies", 193 from the European Patent

192 Cites Resolution Conf. 10.17 (Rev.CoP14) on Animal Hybrids, art. 1(a) and (d).

193 UNFCCC 1992 UNTS vol 1771 p1O7, art 4(5), Kyoto Protocol 1997 https://unfccc.int/ resource/docs/convkp/kpeng.pdf art 10, see also Paris Agreement 2015 UNFCCC Paris 
Office regarding categorisation and "sustainable technologies,"194 and from work by several patent agencies (including the UK and Brazil) for fast track examination of "environmentally friendly" and "green" innovation. 195

One pathway to do this may appear surprising, given the points made above. The ILBI could impose fewer requirements to share the innovation or public interest defences in respect of these technologies and rely on the fact that, based on a traditional incentive and innovation approach to IP, the more power conferred, the more incentive there would be to choose to innovate in this area. Yet even if this approach did encourage more research, the issue would remain of the limits on the innovation and activity which the rights would impose on the activity of others during the term of the patent or while the information was secret. There could be the hope that the instances explored across this contribution of patent owners choosing to share their innovation could lead to increased use by others of ecologically sustainable technology. Yet a key theme across this contribution has been that this approach to sharing cannot and should not be relied upon.

A preferable approach, then, which is indeed also rather market based, would be for a decreased payment to be made to the biodiversity fund by those developing and selling ecologically sustainable solutions. This could encourage innovation in this space. It could also be justified on the basis that such innovators are through this innovation choice already paying debts to the ecosystem which were incurred by removing the MGR or going down to the seabed to analyse it and establish its digital sequence information.

The ILBI negotiations move closer to a solution. The closing remarks of the facilitator of the MGR discussions at IGC3 noted key issues to include how the

Agreement Annex to Decision FCCC/CP/2015/L/9/Rev.1 art 1O(1); Technology Mechanism https://unfccc.int/ttclear/support/technology-mechanism.html and Global Environment Facility under the Poznan Strategic Programme on Technology Transfer Webpage https:// www.thegef.org/topics/technology-transfer and Case Studies https://www.thegef.org/ sites/default/files/publications/GEF-TechTransfer-lowres_final_2.pdf, https://unfccc.int/ resource/docs/publications/tech_for_adaptation_o6.pdf all accessed 4 November 2019.

194 Class Yo2 and Yo4S - EPO webpage, 'Sustainable technologies' https://www.epo.org/ news-issues/issues/classification/classification.html.

195 UKIPO Green Channel https://www.gov.uk/guidance/patents-accelerated-processing; A. Dechezlepretre and E. Lane, 'Fast-tracking green patent applications' wio Magazine (2013), https://www.wipo.int/wipo_magazine/en/2013/o3/article_ooo2.html accessed 4 November 2019 . 
definition of MGR engages with digital information, whether benefit sharing and its modalities and triggers should be mandatory and whether to address IP rights and if so how. ${ }^{196}$ This contribution has sought to contribute to these issues for marine diversity in the ABNJ.

The prospect of commercial development with MGR, private activity in respect of new technologies and increased argument for regard to the protection of ecoystems require a new approach to MGR and benefit sharing. If this is not done, then activity will fall outside the ILBI. This will render the ILBI at best incomplete and at worst undeliverable, with the option to engage more directly with ecological approaches being lost. This contribution has developed a new ecosystem and ecologically-focused approach building on the intersections between law and science, property and openness, commercial products and scientific research, physical and digital, the past and the future, and normative and workable. It has provided a new contribution which can be of use in the ILBI negotiations, in future legal and scientific debates which involve public and private perspectives, and in the development of benefit sharing and its intersection with sustainability, science and other areas of law.

Proposals have been made regarding definitions of MGR; engagement with IP and trade secrets; tracing the place of exclusivity; the timing and funding of activities covered by benefit sharing and a market-based system to encourage innovation in ecologically sustainable areas. They have avoided fragmentation and engaged in intersystemic dialogue. The proposals made here are consistent with existing laws and would ensure that the benefit-sharing goals can be delivered, rather than being cast aside through an unquestioning acceptance of the power of private rights. The proposals do not change IP law, rather they engage with opportunities which exist within IP law for states to introduce some permitted exceptions and require sharing.

It is a challenge to "future proof" entirely the ILBI. But the proposals made here are an important step towards this, for science and for law.

The authors are delighted to acknowledge the significant contribution made to this piece by Dr Olivia Woolley (School of Law University of Aberdeen, shortly to be of Durham University, and research assistance provided by Jack Cameron (graduate of the School of Law University of Aberdeen). We also acknowledge the invaluable contribution to scholarship and to the ongoing negotiations by Arianna Broggiato, Thomas Vanagt, Laura E. Lallier, Geoff Burton and Dominic Muyldermans - authors, alongside Jaspars, of the Mare Geneticum piece to which reference is made in this chapter.

196 Earth Negotiations Bulletin 25 (2018) 2 September 2019. 